\title{
STEP-DAUGHTERS OF ENGLAND
}

\section{British Women Modernists and the National Imaginary}

\section{Jane Garrity}

(Manchester Univ. Press, 2003, Softback, £15.99)

Written by an academic - Garrity is Associate Professor of English at the University of Colorado at Boulder - and published in this country by an academic press, StepDaughters of England is the fruit of meticulous research (100 of its 350 pages are devoted to copious references and an extensive bibliography).

Garrity has adopted as her subject four British women modernists - Dorothy Richardson, Sylvia Townsend Warner, Mary Butts and Virginia Woolf, and sets out to demonstrate how they 'used experimental literary techniques in order to situate themselves as national subjects.' The inclusion of the Dorset writer Mary Butts is perhaps questionable - Ashe of Rings (1925), that 'indecent book about the Greeks and the Downs' as Woolf called it, was summarily rejected by the Hogarth Press and, despite the recent efforts of the American publisher McPherson \& Co., Butts is likely to remain a shadowy figure in English literature between the wars.

The chapter of most likely interest to readers is 'Encoding bi-location: Sylvia Townsend Warner and the primitive erotics of sapphic dissimulation'. Here Garrity confines herself primarily to a reading of Mr Fortune's Maggot and more particularly Lolly Willowes where Warner 'uses displacement to signal the claiming of homoerotic territory, but, rather than by exploding syntax or using fragmentary nonlinear forms, she revolts against confining linguistic structures by playing with binary oppositions.' 
Step-Daughters of England is a weighty contribution to the body of lesbian literary criticism that Warner's fiction has attracted over the last twenty years. This itself is a measure of the novelist's growing stature among academics both here and in America and, as such, is a welcome development, but the title is destined largely for university libraries. Here it may well become required reading for students of Gender Politics, but an abridged 'translation' is also required for the general reader.

Peter Tolhurst 